\title{
Glaciar Relief and Pleistocene Glaciation in Retezat Mountains (Transylvanians Alps, Romania)
}

\author{
Ureda, .* $^{*}$
}

Abstract The article describes the glacial relief and the development of Pleistocene glaciation for one of the most representative mountain units of Romania, the Retezat Mountains, with special attention to the glacial cirques and valleys. Some morphometric elements have been used to analyse the specific way in which the glaciers have modelled the relief of Retezat Mountains - the surface area, the perimeter and circularity index for glacial cirques and depth, valley top width and form ratio for glacial valleys, as well as the relations between them expressed by regression equations. Assimilating the longitudinal profile of the cirques of a logarithmic curve $\mathbf{y}=\mathbf{k}(\mathbf{1 - x}) \mathbf{e}^{-\mathbf{x}}$ that describes the concavity of the longitudinal profile, we found together with the known values 0.5, 1 and 2 of the constant $k$, that describes the concavity of the longitudinal profile, there are cirques that need the new value 1.5. The geomorphological mapping has allowed a reconstruction of the development of the Pleistocene glaciation in this mountain area. In the Lolaia phase, (Riss II), the maximum phase, the glaciers occupied $25 \%$ of the surface of these mountains, reach down to 1035-1100 m.a.s.l., and the altitude of the perennial snow limit is placed at $1646 \mathrm{~m}$, the longest glacier, Lăpuşnicu Mare having $18.1 \mathrm{~km}$. The last glaciers existed in the Younger

Dryas (Beagu phase) in which there were only very small lens shaped glaciers, only in the cirques situated at an altitude of over $2150 \mathrm{~m}$.
B ecause in the international glaciological and geomorphological community the glacial relief and the development of Pleistocene glaciation in the Romanian Carpathians are extremely little known, we present this problem for one of the most representative mountain units in Romania, the Retezat Mountains.

The Retezat Mountains are situated on the west side of the Southern Carpathians, or the Transylvanian Alps, belonging to the Retezat - Godeanu mountain group (fig. 5a), reaching a maximum height of $2509 \mathrm{~m}$ a.s.l. in Peleaga Peak. The whole area extends over 453 $\mathrm{km}^{2}$, but the relief situated in the alpine zone (over $1800 \mathrm{~m}$ a.s.l.) represents $27 \%$ of the surface. As far as geology is concerned, the main characteristic of Retezat Mountains is given by the presence in the central area of the Retezat granitoid syntectonic body, surrounded at its edges by crystalline schists, represented especially by amphibolites and gneisses.

The first observations of the glacial nature of the relief, belonging to Lehmann (1885), were disputed by von Inkey (1892), but E. de Martonne (1907) analysed minutely the morphology of Southern Carpathians, the glacial relief being presented as an unchallenged morphological certainty.

\section{Aspects of the Glacial Relief}

Glacial relief dominates the geomorphological landscape of the Retezat Mountains. The central part of the massif with glacial cirques and valleys, peaks and sharpened ridges, grouped together into two gipfelflur levels, creates a typical alpine landscape called "Făgăraș type relief" by Romanian geomorphologists. In fact, the glacial cirques and valleys are the most representative landforms of the glacial morphogenesis in the Southern Carpathians. In area adjacent to the central zone, the glacial cirques and valleys are moulded in the smooth and rounded levelled surfaces of the Borăscu sculptural complex, producing a "Godeanu landscape type". Because this situation is characteristic of some extended areas from the Romanian Carpathians, we tend to speak (Velcea, 1973) about a Carpathian type glaciation. The glacial cirques from the Romanian Carpathians are called by the locals "căldări " (= cauldron) and "zănoage", their form could be found in the general definition given to the glacial cirques (Evans and Cox, 1974).

The glacial cirques spread between $1670 \mathrm{~m}$ - median floor altitude - (the Capu Slăveiului cirque) and $2200 \mathrm{~m}$ a.sl. (the Păpuşa cirque). The Galeşul cirque reaches the maximum depth of $530 \mathrm{~m}$ and the maximum length of $1975 \mathrm{~m}$, and the Zănoaga-Judele glacial cirque complex reaches $3.5 \mathrm{~km}$ breadth.

Following the orientation of the glacial cirques and valleys - situated further on the glacial cirques - in the Retezat Mountains, (fig. 1) $64.5 \%$ present a Northern general orientation $(\mathrm{N}, \mathrm{NW}$, $\mathrm{NE}$ ) and $35.5 \%$ present a southern one (S,SW, SE). Certain morphographic and morphometric features like the form on the plane, the planimetric form and the

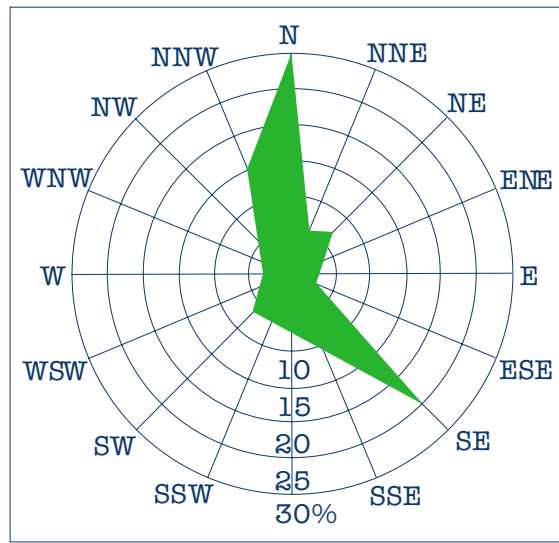

Fig. 1 Orientation of the glacial cirques and valleys in the Retezat Mountains.

sizes of the rock-walls, their slope and the slope of the floor of the cirque, the form of the transversal and longitudinal profiles are elements which make possible the differentiation of some distinct types of cirques and reflect certain morphogenetical characteristics. For example, taking into consideration the form on the plane in the Retezat Mountains, there are all the type of cirques quoted in literature (Benn and Evans, 1998). Taking into account three representative morphometric and morphographic elements, the surface $(\mathrm{S})$, the perimeter $(\mathrm{P})$ and circularity index $\left(\mathrm{CI}=4 \mathrm{~S} / \mathrm{P}^{2}\right)$, and their variations, $\left(\mathrm{S}\right.$ max. $=2.1 \mathrm{~km}^{2}, \mathrm{~S}$ min $=0.12 \mathrm{~km}^{2}, P \max .=7.4 \mathrm{~km}, P \min .2 \mathrm{~km}$, $\mathrm{CI}$ max. $=1.51, \mathrm{CI}$ min. $=0.33$ ), we established that the relations between these 
morphometrical elements being defined by the following equations:

\section{$\mathrm{CI}=1.206-0.091 \mathrm{P}(\mathrm{r}=0.366)$ \\ $\mathrm{CI}=1.039-0.119 \mathrm{~S}(\mathrm{r}=0.209)$}

Because " $r$ " has small values, this suggest a very limited dependence of the circularity index in rapport with the surface and of the perimeter of the glacial cirques.

It has also been followed other morphometrical elements as length (L), width (W), depth (D), L/W ratio, L/D ratio and $\mathrm{D} / \mathrm{W}$ ratio, their values (Table 1) being able to be compared with the specific ones for Bendor Range - Bridge River District(British Columbia) (Evans, 1974), Swedish Lapland (Vilborg, 1977), Central Sweden (Vilborg, 1984), Austrian Alps and Highland of Britain (Embleton and Hamann, 1988; Evans and Cox, 1995). Following, for example, the rapartition on classes of values of the cirques width, 26 of them $(56.5 \%)$ had the width between 500 and $1000 \mathrm{~m}$ (fig. 2), the situation resembling those from the Scandinavian Mountains (Rudberg, 1994).

Starting from the comparison of the longitudinal profile of the cirques with a logarithmic curve of the form $\mathbf{y}=\mathbf{k}(\mathbf{1}-$ $\mathbf{x}) \mathbf{e}^{-\mathbf{x}}$ (Haynes, 1968), for the cirques in the Retezat Mountains together with the values $0.5,1$ and 2 of the constant $k$, that describes the concavity of the longitudi-

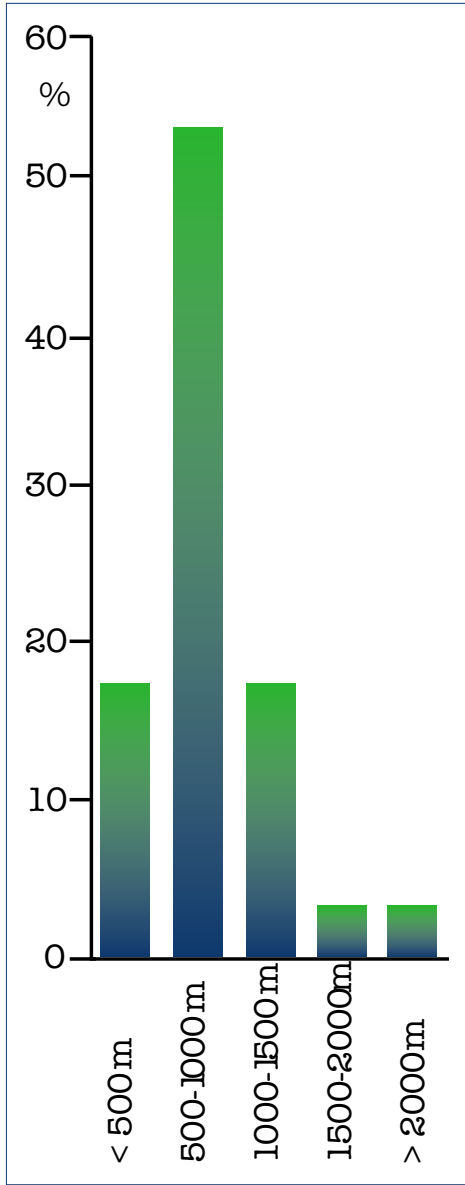

Fig. 2 The histograme of width of glacial cirque in the Retezat Mountains. nal profile, there are cirques that need the new values 1.5 (fig. 3). Taking into account the aspect of the longitudinal profile and the morphogenetic effect of the ice rotational movement (Haynes, 1968),

orthocline cirques (e.g. Lazăru, Gruniu, Văcarea). Following the azimuthal and height distribution of the cirques differentiated by the value of $\mathrm{k}$ (fig. 3a), one may notice that, for example, the major-

Table 1 Some morphometric data of glacial cirques in the Retezat Mountains

\begin{tabular}{|l|r|r|r|}
\hline & Min & \multicolumn{2}{|c|}{ Max } \\
\hline Length (L) & $400 \mathrm{~m}$ & $1975 \mathrm{~m}$ & \multicolumn{2}{|c|}{ Mean } \\
\hline Width (W) & $275 \mathrm{~m}$ & $1600 \mathrm{~m}$ & $727 \mathrm{~m}$ \\
\hline Depth (D) & $130 \mathrm{~m}$ & $530 \mathrm{~m}$ & $294 \mathrm{~m}$ \\
\hline L/W ratio & 0.74 & 2.47 & 1.3 \\
\hline L/D ratio & 1.53 & 5.96 & 3.07 \\
\hline
\end{tabular}

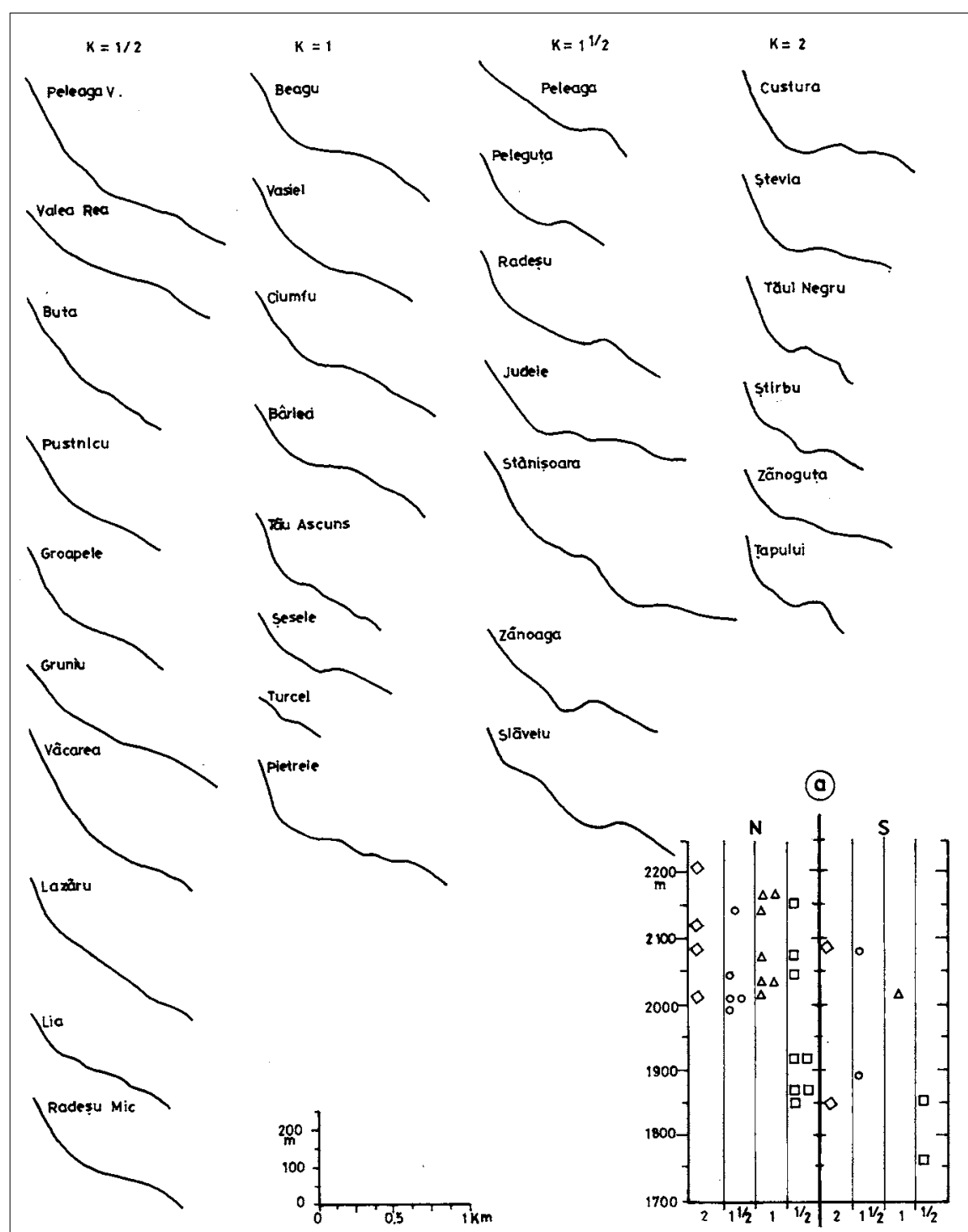

Fig. 3 Logarithmic curves fitted to longitudinal profiles of the cirques from Retezat Mts.; a. altitudinal and azimuthal distribution of the cirques differentiated by the value of $k$.

the values of $\mathrm{k}$ of 2 and 1.5 indicate just the increased efficiency of the glacial erosion even in harder rocks, represented especially by granites and granodiorites. It is revealed that the small values characterize either the cirques situated at lower altitudes, affected by smaller glacial phases (e.g. Buta, Pustnicu, Radeşu Mic), or cirques situated in the area of crystalline schists, and with a status of ity of the cirques with $\mathrm{k}=2$ are situated at over $2000 \mathrm{~m}$ a.s.l. and oriented north.

In order to estimate the asymmetry of the Pleistocene glaciation in this part of the Carpathians, we proceeded to the construction of a cumulative vector diagram (Evans, 1969, 1977). We can find in this way that the length of resultant vector has the value of 10.6, the azimuth of resultant vector has the value of $35^{\circ}$ and 
the strength of resultant vector is $23 \%$ (fig. 4). According to Evans' suggestions for interpretation, with this value, the Retezat Mountains would belong to the areas with weakly asymmetric manifestation of the glacial phenomenon. In our opinion, this situation is due to the major influence of the pre -glacial relief on the installation of the glaciers.

The glacial valleys are morphologic elements well-represented on the geomorphological landscape of the Retezat Mountains, down to $1200-1100 \mathrm{~m}$ a.s.l. The glacial valleys, situated further on the glacial cirques, keep their typical form of glacial trough till 1300-1450 m a.s.l., but they are altered by the postglacial erosion at a lower altitude, especially on the lower part of the transversal profile.

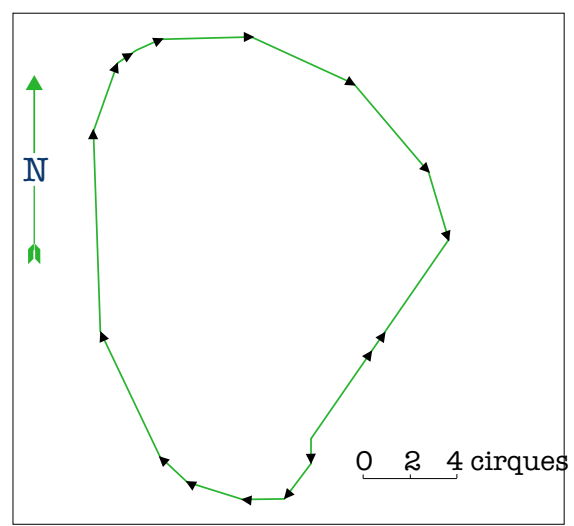

- Fig. 4 Cumulative vector diagram of glacial cirques orientation from Retezat Mountains.

The lengths of glacial valleys in the Retezat Mountains range between 0.7 km, (Buta Mică) and 15.7 km, (Lăpuşnicu Mare). The glacial valleys are characterised by a general gradient with values between $13.8 \%$ at Buta valley and $21.3 \%$, on the Şesele valley, and are characterised by quasi horizontal steps and glacial basins of overdeepenings, but also some important breaks of slope. The ones situated at $1200-1280,1420-1500,1600-1690,1800-1850$ and 1980-2060 $\mathrm{m}$ depend on the polycyclic evolution of the pre-glacial valleys, in fact a specific situation for the Carpathian area (Klimaszewski, 1973).

Taking into consideration that the form ratio (Graf, 1970)

\section{$\mathrm{Fr}=\mathrm{V}_{\mathrm{d}} / \mathrm{WI}$}

where $V_{d}$ is valley depth and WI is the valley top width could be a quantitative expression of the glacial erosion which moulded the pre-existent valleys in a typical way, we calculated that parameter for the upper, middle and lower sector of every glacial valley. The resulting values range between 0.325 for the valleys affected by major glacial phases, Dobrunu Valley for example, and 0.15 for Şesele Valley, affected by a single glacial phase, the mean value is 0.259 , a close value to the minimal ones from Beartooth Mts. in the Rocky Mountains (Graf, 1970). Consequently the values decrease from upstream to downstream, that is from the sectors shaped in several glacial stages to the lower ones, affected by a single glacial stage. The characteristic values are exemplifed by the Pietrele Valley with 0.284 in the upper sector, 0.212 in the middle sector and 0.173 in the lower one, and by Dobrunu Valley with 0.325 on the upper sector, 0.254 in the middle sector and 0.237 on the lower one, or by Râu Bărbat Valley with 0.295 on the upper sector, 0.283 in the middle sector and 0.232 on the lower one.

The relations between the form ratio and the two morphometric elements may be expressed by the following equations

$$
\begin{aligned}
& F r=0.074+0.00094 V_{d} ;(r=0.494) \\
& F r=0.379-0.00015 W I ;(r=0.296) \\
& V_{d}=67.8+0.162 W I ;(r=0.609)
\end{aligned}
$$

the values of " $r$ " suggest a higher dependence of Fr to $V_{d}$ than WI.

\section{Pleistocene Glaciation}

Geomorphological mapping of the glacial relief in the Retezat Mountains, and especially the identification of frontal moraines, together with sporo-palinological data (Pop and others, 1971) in the absence of absolute ages, has allowed a reconstruction of the development of the Pleistocene glaciation (fig.5). Also, using the Höfer method, a method recommended by UNESCO too (Gross and others, 1977), the snow limit corresponding to every glacial stage was calculated by Urdea (1993).

Therefore, in the maximum phase $($ Lolaia $=$ Riss II), the glaciers occupied $25 \%$ of the surface of these mountains, getting down to $1035-1100 \mathrm{~m}$ a.s.l., and the latitude of the perennial snow limit is placed at $1646 \mathrm{~m}$. The most important re-

\section{Table 2 Some reconstructed}

Pleistocene glaciers (Lolaia phase = Riss II) in the Retezat

MountainsMountains

\begin{tabular}{|l|r|r||}
\hline The glaciers & \multicolumn{1}{|c|}{$\begin{array}{c}\text { Length } \\
(\mathrm{km})\end{array}$} & \multicolumn{1}{|c|}{$\begin{array}{c}\text { Surface } \\
\left(\mathrm{km}^{2}\right)\end{array}$} \\
\hline Lăpuşnicu Mare & 18.1 & 40.1 \\
\hline Pietrele & 8.1 & 27.3 \\
\hline Râu Bărbat & 7.9 & 15.5 \\
\hline Râu Alb & 8.8 & 5.3 \\
\hline Dobrunu & 5.8 & 7.5 \\
\hline Paroş & 4.2 & 3.4 \\
\hline Ştevia & 3.8 & 2.9 \\
\hline Şesele & 3.6 & 3.1 \\
\hline
\end{tabular}

constituted glaciers were large (Table 2). The Lăpuşnicu Mare glacier, the biggest in the Retezat Mountains and maybe in all the Romanian Carpathians had a length of $18.1 \mathrm{~km}$ and extended over an area of $40.1 \mathrm{~km}^{2}$. It was formed by the confluence of Bucura $(4.2 \mathrm{~km}$ length and $8.5 \mathrm{~km}^{2}$ area $)$ and Peleaga glacier $(4.4 \mathrm{~km}$ length and $5.8 \mathrm{~km}^{2}$ area), accepting in its inferior sector first the Judele glacier (6.9 $\mathrm{km}$ and $11.2 \mathrm{~km}^{2}$ and then the PaltinuGalbena glacier ( $4.6 \mathrm{~km}$ and $8.1 \mathrm{~km}^{2}$ ) from the Godeanu Mountains. On the northern slope one may notice the large complex Pietrele-Nucşoara with the longest glacial tongue of $8.1 \mathrm{~km}$ and a total surface of $27.3 \mathrm{~km}^{2}$. Its branches which lowered down from the main ridge were the Beagu glacier of $5.4 \mathrm{~km}$ and $4.2 \mathrm{~km}^{2}$, the Galeşu glacier of $4.4 \mathrm{~km}$ and $7.2 \mathrm{~km}^{2}$, the Valea Rea glacier of $3.6 \mathrm{~km}$ and 3.9 $\mathrm{km}^{2}$ and the Stânişoara glacier of $5.5 \mathrm{~km}$ and $6.2 \mathrm{~km}^{2}$. The Râu Bărbat glacier became conspicuous on the east side with $7.9 \mathrm{~km}$ length and $15.5 \mathrm{~km}^{2}$ area and accepted the ice of some hanging glaciers situated under the Văcăria-CusturaPăpuşa- Porțile Închise ridge.

Beside these alpine-type glaciers which spread over an area of $101 \mathrm{~km}^{2}$, there were some plateau glaciers as sucht as the ones which sustained the Fața Zănoagei, Rovine and Scoaba Retezatului valley glacier. These glacial valleys have their origin not in glacial cirques, but in wide flaring areas which spread a little over the adjacent plateau or wide rounded interfluvial areas, characteristic of the Borăscu sculptural complex. In the domain of ridges and peaks ice aprons and ice lids may have existed. Taking into account the Riss II snow limit of $1646 \mathrm{~m}, 39 \%$ of the Retezat Mountains moulded by glacial and supraglacial morphogenetic agents.

Our results make possible a correlation of glacial phases in the Retezat Mountains with those in the Tatra Mts. (Halouzka, 1977) and the Alps (Glückert, 1987) during Upper Pleistocene (Table $3)$. The fact that the snow limits is lower with about $200 \mathrm{~m}$ in Retezat Mountains than in Tatra Mountains is due both to the $4^{\circ} 30^{\prime}$ difference of latitude, and the more continental climate, in this way having poorer precipitations in Romanian Carpathians. Thus, during Würm II, in the Judele stage, the maximum extension stage of the Würm glaciation, the glaciers reached down to almost $1300 \mathrm{~m}$ a.s.l., the glacial cirques and valleys being shaped in the major sculptural landforms of the Riss glaciation. The snow limit was situated around 1783 $\mathrm{m}$, and the longest glaciers, Lăpuşnicu Mare and Pietrele, reached $9.7 \mathrm{~km}$ and respectively $5.5 \mathrm{~km}$. Because of the more arid climate during Würm III, the glaciation had a smaller extension and the glaciers reached down only to $1440 \mathrm{~m}$ 
Table 3 The scheme of correlation of the glacial phases in the Retezat Mts with those in the Tatra Mts and the Alps during the Upper Pleistocene

\begin{tabular}{|c|c|c|c|c|c|c|c|}
\hline \multicolumn{3}{|c|}{ Retezat Mountain } & \multicolumn{3}{|c|}{ Tatra Mountains (Halouzka, 1977) } & \multirow{2}{*}{$\begin{array}{l}\text { The Alps Mountains } \\
\text { (Glückert, 1987) } \\
\text { a }\end{array}$} & \multirow{2}{*}{$\begin{array}{c}\text { Stratigraphy } \\
\text { d }\end{array}$} \\
\hline a & $b$ & c & a & $b$ & c & & \\
\hline & & & $\mathrm{H}$ & 2022 & 2201 & Kromer & Preboreal \\
\hline Beagu & 2150 & 2203 & $\mathrm{WH}$ & 1838 & 2075 & Egesen & Younger Dryas \\
\hline Ştevia & 2105 & 2136 & Polana pod Vysokou II & 1838 & 2075 & Egesen & Middle Dryas \\
\hline Borzii Vineți & 1940 & 2103 & Polana pod Vysokou I & 1544 & 1902 & Gschnitz-Clavadel & Old Dryas \\
\hline Văsiel & 1860 & 2058 & Rybi potok & 1449 & 1825 & Flisur-Steinach & \\
\hline Valea Rea & 1720 & 1988 & Prostredna polana II & 1350 & 1759 & Konstanz-Hurden & \\
\hline Gențiana & 1640 & 1948 & Prostredna & 1310 & 1740 & Zürich & Würm III \\
\hline Stâna de Râu & 1570 & 1914 & Veza & 1213 & 1683 & Stein am Rhein & \\
\hline Stânişoara- Pietrele & 1440 & 1838 & Tatranska- Lomnica & 1102 & 1640 & Schaffhausen & \\
\hline Judele & 1335 & 1783 & Stosy & 1094 & 1631 & Aying & Würm II \\
\hline
\end{tabular}

a, glacial phase; $b$, altitude of terminal moraine; c, snow-limit; $d$, stratigraphy for Central and Northern Europe.

during Stânişoara-Pietrele stage. During the following stages the Würm glaciation became smaller and smaller extension. At the end of the Würm, during Valea Rea stage, the glaciers reached down only to $1720 \mathrm{~m}$, the snow limit being situated at $1988 \mathrm{~m}$. The glaciers had changed from alpine-type glaciers into pyrenean glaciers, with short tongues, less than $2 \mathrm{~km}$ in length.

During the Old and Middle Dryas, the characteristic glaciers are cirque ones, situated at over $1860 \mathrm{~m}$, spread over only $8.5 \%$ of the Retezat surface. The glaciers sorrounded by steep walls were gradually invaded by debris and changed into black glaciers and then into secondary rockglaciers.

In Younger Dryas, during the Beagu stage, there were very small glaciers only in the cirques situated at over 2150 $\mathrm{m}$ and the snow limit was over $2200 \mathrm{~m}$ a.s.l. Subsequently, the considerable improvement of the climate, noticed by the palynological spectrum (Pop and others, 1971), caused definitive disappearance of glaciers from the Retezat Mountains. In the Holocene only the rockglaciers continued their evolution, in the periglacial morphogenetic storey (Urdea, 1997).

\section{Aknowledgements}

The autor wish to thank to Dr. Ian S. Evans, Dr. Valerie Haynes and Prof . David Sugden for their constructive and honest comments and suggestion and for assistance with the English on the manuscript.

\section{References}

Benn, D.I., Evans, D.J.A.. 1998. Glaciers \& Glaciation, Arnold, London, 734.
Embleton, C+., Hamann, C. 1988. A comparison of cirque forms between Austrian Alps and the Highlands of Britain, Z.f. Geomorphologie, N.F. 70, 75-93.

Evans, I.S. 1969. The geomorphology and morphometry of glacial and nival areas. In Chorley R.J. ed. Water, Earth and Man, Methuen, London, 369-380.

Evans, I.S. 1974. The geomorphometry and asymmetry of glaciated mountains. (Ph.D. thesis, University of Cambridge, 527 ).

Evans, I.S. 1977. World-wide variations in the direction and concentration of cirque and glacier aspects, Geografiska Ann. 59 A, 3-4, 151-175.

Evans, I.S., Cox, N.J. 1974. Geomorphometry and the operational definition of cirques, Area, 6, 2, 150-153.

Evans, I.S., Cox, N.J. 1995. Rhe form of glacial cirques in the English Lake District, Cumbria, Z.f. Geomorphologie, N.F. 39, 2, 175-202.

Glückert, G. 1987. Zur letzten Eiszeit im alpinen und nordeuropäischen Raum, Geographica Helvetica, 42, 2,

Graf, W.L. 1970. The geomorphology of the glacial valley cross section, Arctic and Alpine Research, 2, 4, 303-312.

Gross, G., Kerschner, H., Patzelt, G. 1977. Methodische untersuchungen über die Schneegrenze in alpinen Gletschergebieten, Z.f. Gletscherkunde u. Glazialgeologie, 12, 2, 223-251.

Halouzka, R. 1977. Stratigraphical subdivision of sediments of the last glaciation in the

Czechoslovak Carpathians and their correlation with the contemporary alpine and north-european glaciation, Pr. 73/1/24, IGCP, Quaternary glaciations in the Northern Hemisfere, Prague, Report nr. 4, 83-89.

Haynes, V.M. 1968. The influence of glacial erosion and rock structure on corries in Scotland, Geografiska Ann. 50 A, 4, 221-234.

Inkey, B.v. 1892. Die Transsylvanischen Alpen von Rotenturmpasse bis zum Eisernen Tor, Math.u.naturwisseschaftliche Berichte aus Ungarn, IX, 20-53.

Klimaszewski, M. 1973. Conditions essential to the pleistocene glaciation of the Carpathians, Folia Geographica, Geographia Physica, VII, 5-26.

Lehmann, P.W. 1885. Die Südkarpaten zwischen Retjezat und Königstein, Zeitschr. d. Geseellschaft f. Erdkunde Berlin, XX , 325-336, 346-364.

Martonne, Emm. de. 1907. Recherches sur l' évolution morphologique des Alpes de Transylvanie (Karpates méridionales), Rev. de géogr. annuelle, I (1906-1907), 286 pp.

Pop. E., Lupşa, V., Boşcaiu, N. 1971. Diagrama sporo-polinică de la Tăul Zănoguții (Munții Retezat). In Progrese în palinologia românească, Edit Academiei, Bucureşti, 219-225.

Rudberg, S. 1994. Glacial cirques in Scandinavia, Norsk geogr. Tidsskr., 48,179-197.

Urdea, P. 1993. Considerații asupra manifestării glaciației cuaternare în Munții Retezat, Stud. cerc. de geografie, XL, 65-72.

Urdea, P. 1997. Aspectas concerning postglacial and present-day landforms evolution in Southern Carpathians, Acta Facultatis Rerum Naturalium Universitatis Comenianae, Geographica, Bratislava, 40, 107-117.

Velcea, V. 1973. De l' éxistence d' une glaciation de type carpatique, $R e v$.

géogr.alpine, LXI, 2, 223-230.

Vilborg, L. 1977. The cirque forms of Swedish Lapland, Geografiska Ann. 59 A, 3-4, 89-150..

Vilborg, L. 1984. The cirque forms of Central Sweden, Geografiska Ann. 66 A, 1-2, 41-77. 